\title{
Spectrophotometric Determination of the First Hydrolysis Constant of Praseodymium (III)
}

\author{
Roberto González-Mendoza, ${ }^{1}$ Hilario López-González, ${ }^{1 *}$ and Alberto Rojas-Hernández ${ }^{2,3}$
}

${ }^{1}$ Instituto Nacional de Investigaciones Nucleares. Dirección de Investigación Científica, Gerencia de Ciencias Básicas, Departamento de Química. Apdo. Postal 18-1027, 11801, México. D.F. México. hilario.lopez@inin.gob.mx.

2 Universidad Autónoma Metropolitana-Iztapalapa, Departamento de Química, Área de Química Analítica, Apdo. Postal: 55-534, 09340 México D. F., México. suemi918@xanum.uam.mx

${ }^{3}$ Universidad Nacional Autónoma de México, Facultad de Estudios Superiores-Cuautitlán. Unidad de Investigación Multidisciplinaria. Laboratorio de Fisicoquímica Analítica. Km. 2.5. Carretera Cuautitlán-Teoloyucan. San Sebastián Xhala. 54714 Cuautitlán Izcalli, Estado de México, México.

Received November 25, 2009; Accepted March 29, 2010

\begin{abstract}
The behavior of the trivalent ion praseodymium in $2 \mathrm{M}$ of $\mathrm{NaCl}$ at $303 \mathrm{~K}$ and in $\mathrm{CO}_{2}$ free conditions, was studied. Spectrophotometric titrations of the soluble species were used, in order to obtain the value of the first hydrolysis constant of $\operatorname{Pr}(\mathrm{III})$. The data obtained were treated with both the program SQUAD and by a graphic method, respectively. The result obtained using SQUAD was $\log * \beta_{1}=-8.94 \pm 0.03$, while it was $\log * \beta_{1}=-8.77 \pm 0.03$, when calculated graphically. These results are similar to the value obtained previously with the potentiometric method.

Key words: Hydrolysis of $\operatorname{Pr}(\mathrm{III})$, Hydrolysis Constants, Spectrophotometric Titrations, SQUAD.
\end{abstract}

\section{Introduction}

One of the most important problem area nuclear technologies is the safe handling and the storage of spent nuclear fuels [1]. The lanthanides, some of them are products of uranium nuclear fission, and are analogues of trivalent elements of actinides [2]. The praseodymium is analogue with the protactinium. Therefore, deposition of non-or radioactive wastes in subsurface repositories of salt beds or ocean has generated interest in the complexation of the REE ions in the various oxidation states with hydrophilic ligand in nearly neutral solution is especially needed because complexation strongly affects their mobility [1]. Essential information on actinide chemistry in ground water is lacking. The hydrolysis of praseodymium has been studied by several methods [3-12]. However, the data are different, because of experimental conditions employed such as different ionic strength, temperature, concentrations of the praseodymium and $\mathrm{pH}$ range. Spectrophotometric titrations can be required the use of a computer program to calculate the constants. One such program is SQUAD (stability quotients from absorbance data) [13] which considers only soluble species. SQUAD, a FORTRAN IV-based program is capable of calculating simultaneously, or individually, overall stability constants (of the concentration type) for any species formed in systems containing up to two metals and two ligands. The method is therefore capable of yielding, from appropriate
Resumen. Se estudió el comportamiento del ion trivalente praseodimio, en el medio $2 \mathrm{M}$ de $\mathrm{NaCl}$ a $303 \mathrm{~K}$ y en condiciones libres de $\mathrm{CO}_{2}$. Para obtener el valor de la primera constante de hidrólisis del Pr(III), se empleó la titulación espectrofotométrica de las especies solubles. Los datos obtenidos fueron tratados con el programa de cómputo SQUAD y un cálculo gráfico, respectivamente. El valor obtenido con el programa de cómputo SQUAD fue $\log ^{*} \beta_{1}=-8.94$ \pm 0.03 , en tanto que el calculado gráficamente fue $\log * \beta_{1}=-8.77 \pm$ 0.03 . Estos resultados para el valor de la primera constante de hidrólisis del praseodimio son similares al valor obtenido previamente con el método potenciométrico.

Palabras clave: Hidrólisis de $\operatorname{Pr}(\mathrm{III})$, constantes de formación, titulaciones espectrofotométricas, SQUAD.

absorbance data, acid association constants, metal-ion hydrolysis constants, and stability constants of simple and polynuclear complexes. The non linear least-squares method is based on the minimization of function $U$, given by equation (1):

$$
\mathrm{U}=\Sigma(\Delta \mathrm{F})^{2}=\Sigma\left(\mathrm{F}_{\text {calculated }}-\mathrm{F}_{\text {experimental }}\right)^{2}
$$

The input file data for SQUAD includes the $\mathrm{pH}$ measured, the metal concentration, and a chemical model that includes stoichiometry and estimated values of formation constants of the species present during titrations. The program SQUAD utilizes the UV/Vis absorbance values. The program SQUAD provides the refined values of formation constants, as well as a very complete statistical analysis of the data.

The absorption spectra form the base for the quantitative determination of many of the individual elements in the lanthanoides series [14].

Spectrophotometry is fundamentally applied to species in solution, measuring the radiation that was absorbed by said species. There are two basic methods used for spectrophometric analysis of the rare earth elements [15]: one uses the absorption spectrum of the colored ions and the other one is based upon the absorption spectrum developed by the formation of colored complexes. Those elements from the rare earths that produce colored complexes with non colored anions (like oxides, nitrates, chlorides and sulfates) show bands of absorp- 
tion in the ultraviolet (UV, 200 to $400 \mathrm{~nm}$ ) or visible (Vis, 400 to $750 \mathrm{~nm}$ ) regions of the electromagnetic spectrum.

Various lanthanoid cations with $3^{+}$charges are colorful, generally green, pink, and yellow; these colors come from electronic transitions $f-f$, in analogue form to $d-d$ transitions in transition metals. Nonetheless, compared to the latter, the lanthanoides $4 f$ orbital have deeply penetrated the atom and the widening effect that comes from the vibrations of the ligands is minimal [14]. Besides, the absorptions come in very precise wavelengths, of the sort of line spectra with narrow bands, in contrast with the wide absorptions of transition metals. Praseodymium's absorption spectrum has particularly simple constitution [16]. Within the wavelength interval of 400 to $700 \mathrm{~nm}$, it presents four absorption bands whose absorption maximum values are placed as follows: 444.5, 469.0, 482.2 and $588.5 \mathrm{~nm}$.

In spectrophotometric titrations commonly the measured property is the absorbance in order to obtain titration curves, the equivalence points of titration reactions or stability constants of species in the solution's titration, because the nature and concentration of the absorbent species, change. Spectrophotometric titrations are carried out in recipients in whom the optical path length of monochromatic light is constant. The method is based in two simple relations or ideal absorption laws: absorbance is directly proportional to the concentration of the absorbent species (Beer-Lambert law) and the additivity of the absorption of the different absorbent species (Additivity law) [17]. Absorption in these regions involves transformations of the molecules in their external electrons, going from the fundamental to the excited state [18]. To accomplish this excited state, energy absorption is needed, UV-Vis radiations for example, these two being the ones that make electrons go to greater energy orbital $[19,20]$.

Their most common oxidation state praseodymium is III [14]; type $\operatorname{Pr}_{2} \mathrm{O}_{3}$ oxides, and in aqueous solution the $\operatorname{Pr}\left(\mathrm{H}_{2} \mathrm{O}\right)_{n}^{3+}=\mathrm{Pr}^{3+}$ ions are formed $[9,14]$ and are first hydrolyzed in water through the chemical equilibrium:

$$
\operatorname{Pr}\left(\mathrm{H}_{2} \mathrm{O}\right)_{n}^{3+}+\mathrm{H}_{2} \mathrm{O} \rightleftarrows \operatorname{Pr}\left(\mathrm{H}_{2} \mathrm{O}\right)_{(n-1)}(\mathrm{OH})^{2+}+\mathrm{H}_{3} \mathrm{O}^{+}
$$

\section{Praseodymium (III) hydrolysis}

The reaction of any metallic ion with water ions is called hydrolysis [3]; this reaction, along with the redox reactions, controls the behavior of lanthanoides in solution.

The hydrolysis of Praseodymium may be represented by the global formation equilibria, such as:

$$
\operatorname{Pr}\left(\mathrm{H}_{2} \mathrm{O}\right)_{n}^{3+}+j \mathrm{H}_{2} \mathrm{O} \rightleftarrows \operatorname{Pr}\left(\mathrm{H}_{2} \mathrm{O}\right)_{(n-j)}(\mathrm{OH})_{j}^{3-j}+j \mathrm{H}_{3} \mathrm{O}^{+}
$$

and taking the law of mass action into consideration, we can define their equilibrium constants as:

$$
* \beta_{j}=\frac{\left[\operatorname{Pr}\left(\mathrm{H}_{2} \mathrm{O}\right)_{(n-j)}\left(\mathrm{OH}^{-}\right)_{j}^{(3-j)}\right]\left[\mathrm{H}_{3} \mathrm{O}^{+}\right]^{j}}{\left[\operatorname{Pr}\left(\mathrm{H}_{2} \mathrm{O}\right)_{n}^{3+}\right]}=\frac{\left[\operatorname{Pr}\left(\mathrm{OH}^{-}\right)_{j}^{(3-j)}\right]\left[\mathrm{H}^{+}\right]^{j}}{\left[\operatorname{Pr}^{3+}\right]}
$$

Hydrolysis reactions are affected when the conditions in which they are carried out change. One of these conditions, which have not received enough attention, is ionic strength. There are only a few literature works about environments such as sea water, and others with higher ionic strength like brine (used in salt mines for radioactive waste storage); and that is the source of our interest in providing knowledge about hydrolysis constants in high ionic strength environments. Therefore, in this work the first hydrolysis constant of praseodymium was determined by spectrophotometric methods in the same condition with López-González, et al. [12] because the IUPAC [21] recommends using two methods or more.

With this panorama ahead of use, the aim this research was to know the behavior of the hydrolysis of $\mathrm{Pr}^{3+}$, through the determination of the first hydrolysis constant in ionic strength of $2 \mathrm{M}$ of $\mathrm{NaCl}$ and at a temperature of $303 \mathrm{~K}$ by spectrophotometric technique using the program SQUAD [13]; as well as a graphic method [22].

\section{Results and discussion}

\section{$\mathrm{pC}_{\mathrm{H}} / \mathrm{pH}$ relationship}

Potentiometric calibration line was obtained on $\mathrm{pH}$ measurement of solutions containing defined amounts of $\mathrm{H}^{+}$or $\mathrm{OH}^{-}$. The $\mathrm{pH}$ measurements were corrected by means of this equation: $\mathrm{pC}_{\mathrm{H}}=(1.070 \pm 0.003) \mathrm{pH}+(0.180 \pm 0.009)(\mathrm{r}=0.9993)$ for $2 \mathrm{M} \mathrm{NaCl}$. The result confirms the influence of the ionic strength in the measurements of $\mathrm{pH}$ in accordance to the observations by Feldman [23].

\section{UV-Vis spectrophotometric calibration curves}

Figure 1 shows the absorption spectra of each of the $\operatorname{Pr}(\mathrm{III})$ solutions obtained in the range 200 to $700 \mathrm{~nm}$ in $2 \mathrm{M} \mathrm{NaCl}$ at $\mathrm{pH} 3$ and $303 \mathrm{~K}$. Spectra of concentrations ranging was from 0.0001 to $0.65 \mathrm{M}$. It can be noted that in the UV region (200 to $400 \mathrm{~nm}$ ) there is a wide band between $1 \times 10^{-4} \mathrm{M} \leq[\operatorname{Pr}(\mathrm{III})]$ $\leq 0.065 \mathrm{M}$. For the absorption band of $215 \mathrm{~nm}$ (Figure 1), is to determine low concentration of praseodymium. Furthermore in this first region, the band between $0.065 \mathrm{M} \leq[\operatorname{Pr}(\mathrm{III})] \leq 0.65$ $\mathrm{M}$, at least one more absorption band appears in the region ( 250 to $400 \mathrm{~nm}$ ). The band transitions described in the UV region might be due to electronic transitions of the ligands or charge transfer, different to $f-f$, because they are wide.

On the other hand, and in agreement with Treadwell [16], in the visible region three narrow absorption bands $(443,468$, and $481 \mathrm{~nm}$ ) are observed between $0.026 \mathrm{M} \leq[\operatorname{Pr}(\mathrm{III})] \leq 0.65$ M. The absorption band of $589 \mathrm{~nm}$ and a shoulder at $596 \mathrm{~nm}$ (Figure 1) are interesting, because, we can determine high concentration of praseodymium.

Even more, the concentration interval of praseodymium for the achievement of Beer-Lambert law have been established. At the wavelength of $215 \mathrm{~nm}$, was observed between $1 \times 10^{-4} \mathrm{M} \leq[\operatorname{Pr}(\mathrm{III})] \leq 0.026 \mathrm{M}$. At the wavelengths of 


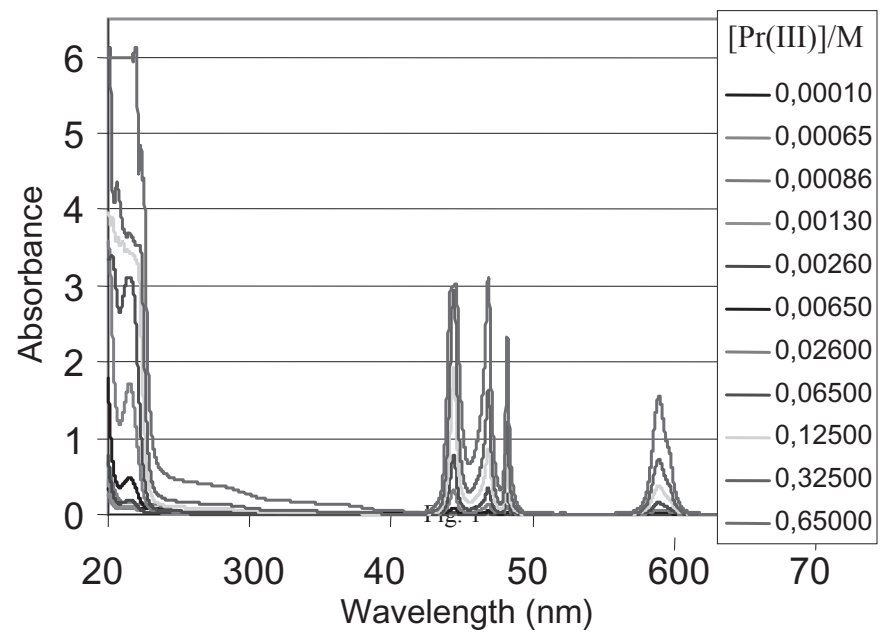

Fig. 1. UV-Vis absorption spectra for each one of the solutions of $\mathrm{Pr}$ (III) prepared in this work in $2 \mathrm{M} \mathrm{NaCl}$ at $\mathrm{pH} 3$ and $303 \mathrm{~K}$.

$443 \mathrm{~nm}, 468 \mathrm{~nm}$, and $481 \mathrm{~nm}$ the Beer-Lambert law follows between $0.0026 \mathrm{M} \leq[\operatorname{Pr}(\mathrm{III})] \leq 0.325 \mathrm{M}$. Finally, at $589 \mathrm{~nm}$, the interval was $0.026 \mathrm{M} \leq[\operatorname{Pr}(\mathrm{III})] \leq 0.65 \mathrm{M}$. These results are shown in Table 1.

\section{Determination of the first hydrolysis constant of $\operatorname{Pr}(\mathrm{III})$ in 2M NaCl by UV-Vis spectrophotometry}

The value of the first hydrolysis constant of $\operatorname{Pr}(\mathrm{III})$ was determined using UV/Vis titration in a $\mathrm{CO}_{2}$ free atmosphere at 303 K. In this work, absorption between 210 and $249 \mathrm{~nm}$ of the first band were chosen as the analytical wavelengths for the determination the first hydrolysis constant of praseodymium. This wavelength interval was chosen due to their best values of absorbance change with the $\mathrm{pH}$. Figure 2 shows the UV/Vis absorption spectra of the titration of $0.00086 \mathrm{M} \operatorname{Pr}(\mathrm{III})$ with $0.005 \mathrm{M} \mathrm{NaOH}$ carried out in $2 \mathrm{M} \mathrm{NaCl}$ at different $\mathrm{pH}$ values. Each curve in Figure 2 represents the UV/Vis absorption spectrum of the Pr solution at each titration $\mathrm{pH}$. The absorption values (in the range 210 to $449 \mathrm{~nm}$ ) shown in Figure 2, the solution $\mathrm{pH}$ (in the range 3.91 to $8.71 \mathrm{pH}$ ), and the $\operatorname{Pr}(\mathrm{III})$

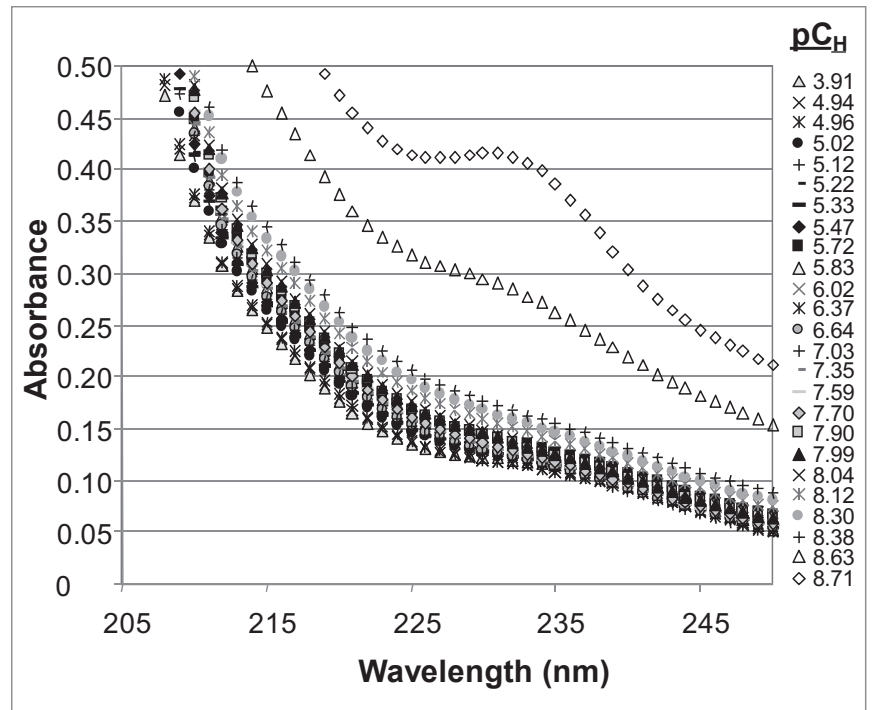

Fig. 2. Typical absorption UV spectra for the titration of $[\operatorname{Pr}(\mathrm{III})]$ $0.001 \mathrm{M}$ with $\mathrm{NaOH}$ in $2 \mathrm{M} \mathrm{NaCl}$ at $303 \mathrm{~K}$.

concentration were used to fed both the SQUAD program and the graphic method.

\section{Determination of the first hydrolysis constant of praseodymium(III) by SQUAD}

Figure 2 shows a bathochromic shift of the main UV transition, when $\mathrm{pH}$ becomes basic (from $210 \mathrm{~nm}$ to $230 \mathrm{~nm}$ ), just before the precipitation of a solid, most probably $\operatorname{Pr}(\mathrm{OH})_{3(\mathrm{~s})}$. This behavior could be taken as an indicative of the formation of $\operatorname{Pr}\left(\mathrm{OH}_{2}\right)_{5}(\mathrm{OH})^{2+}\left(=\operatorname{Pr}(\mathrm{OH})^{2+}\right)$ species.

The computer program SQUAD [13] was used to determine the first hydrolysis constant of $\operatorname{Pr}(\mathrm{III})$, as well as to compare it with the previously calculated with the potentiometric method [12]. The data range used as input for the program SQUAD was selected as follows: The initial point was taken after the excess acid was neutralized and the end point was selected just before $\operatorname{Pr}(\mathrm{OH})_{3(\mathrm{~s})}$ precipitation started, according to the first derivative Figure $3 \mathrm{~b}$ and in range the absorbance values between 0.05 to 1.5 . Several chemical models were

Table 1. Beer-Lambert law ranges of validity for the UV-Vis absorption bands of $\operatorname{Pr}(\mathrm{III})$ in $2 \mathrm{M} \mathrm{NaCl}$ at $\mathrm{pH} 3$.

Wavelength regions of electronic transitions

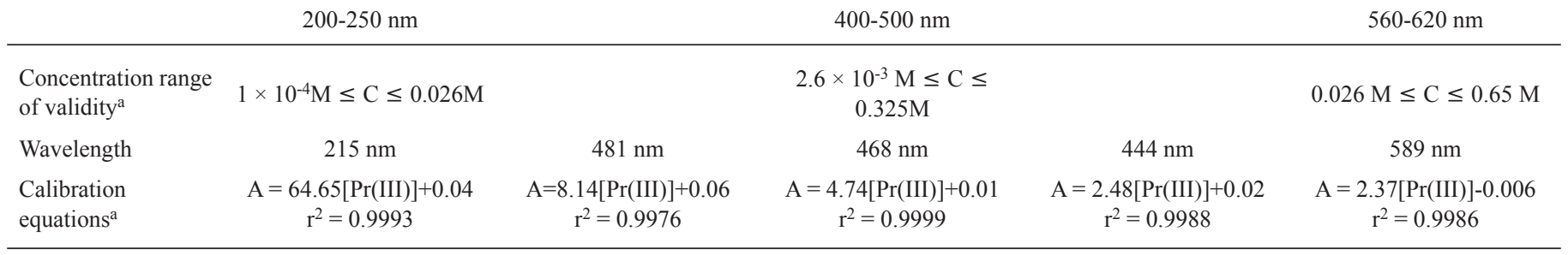

${ }^{a} \mathrm{~A}=$ absorbance and $[\mathrm{Pr}(\mathrm{III})]=\mathrm{C}=$ praseodymium (III) molarity. 
used, but the better is showed here. SQUAD calculates overall stability constants values by mean of a nonlinear least-squares approach. The data for SQUAD calculations are UV/Vis absorption data, $\operatorname{Pr}(\mathrm{III})$ concentration, and a chemical model to describe the system (i.e. $\operatorname{Pr}_{(\mathrm{aq})}{ }^{3+}+\mathrm{H}_{2} \mathrm{O} \leftrightharpoons \mathrm{Pr}(\mathrm{OH})^{2+}+\mathrm{H}^{+}$). The first hydrolysis constant of $\mathrm{Pr}^{3+}$ obtained with the spectra of Figure 2, using SQUAD was $\log * \beta_{1}=-8.91 \pm 0.19$, and using SQUAD only with the absorbance data at $215 \mathrm{~nm}$ was $\log * \beta_{1}=-8.94 \pm 0.03$, as shown in Table 2 .

\section{Determination of the first hydrolysis constant of praseodymium(III) by graphic method}

The absorbance- $\mathrm{pC}_{\mathrm{H}}$ curves of praseodymium at 215,230 , 444, 468, 481, and $589 \mathrm{~nm}$ are show in Figure 3a. All the curves show that the absorbance of the praseodymium increase in the $\mathrm{pH}$ range of 8.4 to 8.8 and is constant below $\mathrm{pH} 8.4$ and above $\mathrm{pH} 8.8$ (including in the inset of the Figure 3a). At those wavelengths was calculated the first hydrolysis constant of praseodymium using the derivate graph, but, the Figure $3 \mathrm{~b}$ shows the best absorbance $/ \mathrm{pC}_{\mathrm{H}}$ curve and the curve of its first derivative with the solid line, and the dashed line corresponds to the best fit to the experimental data with equilibrium constant and molar absorptivity coefficients at a wavelength of $215 \mathrm{~nm}$ obtained with SQUAD refinement. In principle, the maximum of the first derivative indicates an estimator of $\log ^{*} \beta_{1}$ value [22], because it signals the inflection point of the sigmoid absorbance $/ \mathrm{pC}_{\mathrm{H}}$ curve. The estimator obtained by this graphic method is $\log * \beta_{1}=-8.77 \pm 0.03$. The parameters obtained for this refinement are shown in Table 2 and the molar absorptivity coefficients determined during the same refinement are shown in Figure 4. The great uncertainty for the $\log * \beta_{1}$ and the shape of the molar absorptivity coefficient of $\operatorname{Pr}(\mathrm{OH})^{2+}$ obtained with SQUAD may be due to the lack of information of the $\operatorname{Pr}(\mathrm{OH})^{2+}$ species before the $\operatorname{Pr}(\mathrm{OH})_{3(\mathrm{~s})}$ precipitation. In fact, the spectra for $\mathrm{pH} 8.63$ and 8.71 of the Figure 2 were not included in the SQUAD refinement (because the beginning of precipitation of $\operatorname{Pr}(\mathrm{OH})_{3(\mathrm{~s})}$ was observed for $\mathrm{pH}$ around 8.5); nevertheless these data are necessary to calculate the first hydrolysis constant from the first derivative method. This could be the reason why the estimator obtained with the first derivative is lower than that obtained with SQUAD.

Statistical comparison of the $-\log * \beta_{1}$ estimators with the value obtained potentiometrically and reported in the literature by López-González et al. [12] are also shown, following Miller and Miller [24], at a significance level of 95\% (Table 2).

The first hydrolysis constant value of the $\operatorname{Pr}(\mathrm{III})$ reported in scientific literature and that obtained in this work are presented in Table 3. As well as other rare earths, the authors that have obtained it may report different values. These differences may be attributed to the fact that most of the investigations were made with concentrated solutions of the element and in small $\mathrm{pH}$ intervals. The affinity of the lanthanoid ions for the carbonate ions were taken into account only in few cases. So far not all constants are known for a specific element, so a complete description of the hydrolytic behavior has not been achieved.

The reaction of $\operatorname{Pr}(\mathrm{III})$ with water has been studied in several works. The most usual method has been the potentiometric [4-6, 8-12]. Only one work has used solvent extrac-

Table 2. First hydrolysis constant obtained by spectrophotometry from selected data before precipitation of $\mathrm{Pr}(\mathrm{OH})_{3(\mathrm{~s})}$ in $2 \mathrm{M} \mathrm{NaCl}$ and $303 \mathrm{~K}$. $[\operatorname{Pr}(\mathrm{III})]_{\text {total }}=0.00086 \mathrm{M}$. Statistical comparison of the $-\log * \beta_{1}$ estimators with the value obtained potentiometrically and reported in the literature by López-González et al. [12] are also shown, following Miller and Miller [24], at a significance level of 95\%.

\begin{tabular}{|c|c|c|c|c|}
\hline \multicolumn{5}{|c|}{$-\log * \beta_{1}$} \\
\hline $\operatorname{Pr}(\mathrm{OH})^{2+}$ & $-8.76 \pm 0.02$ & $-8.91 \pm 0.19$ & $-8.94 \pm 0.03$ & $-8.77 \pm 0.03$ \\
\hline Sample size & 20 & 720 & 20 & 5 \\
\hline$F_{\text {calc }}$ & - & $90.3>$ & $0.4<$ & $2.3<$ \\
\hline $\begin{array}{c}H_{\mathrm{o}} \text { : } \\
\text { variances equal }\end{array}$ & & rejected & non-rejected & non-rejected \\
\hline$t_{\text {calc }}$ & - & $17.91>$ & $22.15>$ & $0.91<$ \\
\hline$t_{\text {crit }}$ & - & 1.96 & 1.96 & 2.00 \\
\hline $\begin{array}{c}H_{\mathrm{o}} \text { : } \\
\text { means equal }\end{array}$ & & rejected & rejected & non-rejected \\
\hline
\end{tabular}

a 20 spectra were introduced in the $210 \leq 1 \leq 250 \mathrm{~nm}$ interval and 40 absorbance values of each spectra were introduced with a step of $\Delta \lambda=1 \mathrm{~nm}$ and in the $3.9<$ $\mathrm{pC}_{\mathrm{H}}<8.12$ range.

${ }^{b}$ estimated from the 20 data of absorbance $/ \mathrm{pC}_{\mathrm{H}}$ curve at $215 \mathrm{~nm}$ in the $3.9<\mathrm{pC}_{\mathrm{H}}<8.12$ range, fixing the molar absorptivity coefficients (for $\mathrm{Pr}^{3+} 317 \mathrm{~L} \mathrm{~mol}^{-1} \mathrm{~cm}^{-}$ ${ }^{1}$ and $\left.\operatorname{Pr}(\mathrm{OH})^{2+} 753 \mathrm{~L} \mathrm{~mol}^{-1} \mathrm{~cm}^{-1}\right)$, calculated in the refining described in (a).

c estimated from the first derivative of absorbance $/ \mathrm{pC}_{\mathrm{H}}$ curve at $215 \mathrm{~nm}$, probably deviated by precipitation of $\operatorname{Pr}(\mathrm{OH})_{3(\mathrm{~s})}$. 

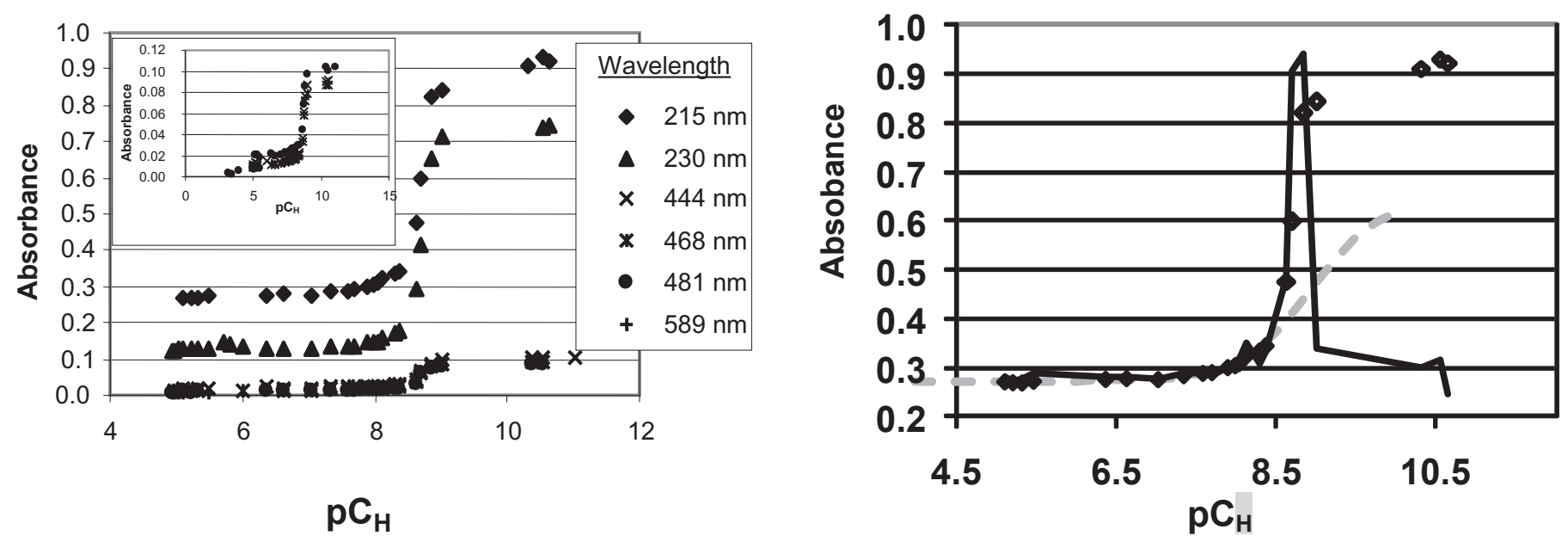

Fig. 3. a) Curves of absorbance as a function of $\mathrm{pC}_{\mathrm{H}}$, in $2 \mathrm{M} \mathrm{NaCl}$ at $303 \mathrm{~K}$, for several wavelengths. The detail shows for the absorbance band at 444, 468, 481 and $589 \mathrm{~nm}$, respectively. b) Experimental absorbance values as a function of $\mathrm{pC}_{\mathrm{H}}$ for a $215 \mathrm{~nm}$ wavelength are shown with markers. Fill markers represent points for solutions in absence of $\operatorname{Pr}(\mathrm{OH})_{3(\mathrm{~s})}$ and empty markers represent points for solutions in presence of $\operatorname{Pr}(\mathrm{OH})_{3(\mathrm{~s})}$. The first derivative of this curve is represented with the solid line while the dashed line corresponds to the best fit to the experimental data with equilibrium constant and molar absorptivity coefficients obtained with SQUAD.

tion methods [7] and the values reported in those papers are the lesser in Table 3. The $\operatorname{Pr}(\mathrm{III})$ concentrations in the first method were situated between $0.0001 \mathrm{M}$ and $1 \mathrm{M}$, while in the second method praseodymium concentration were in the order of $10^{-7} \mathrm{M}$. The ionic strength was studied in a wide interval $0.02-0.3 \mathrm{M}, 3 \mathrm{M}$ and $3 \mathrm{~m}$, but many data are required to predict the influence of this parameter in the hydrolysis element's behavior. The differences between the values reported by Guillaumot et al. [7] and present work with the others is notorious, and might be due to the influence of the carbonate ions in those works.

The first hydrolysis constant of $\operatorname{Pr}(\mathrm{III})$ obtained using SQUAD [13] and potentiometric methods [12] are similar but statistically different, as shown in Table 2 . No polynuclear species of this element are formed yet, in agreement with the expectations from the work of Ciavatta et al. [9].

Table 3. Comparison of the first hydrolysis constant of praseodymium for literature data and those obtained in this work.

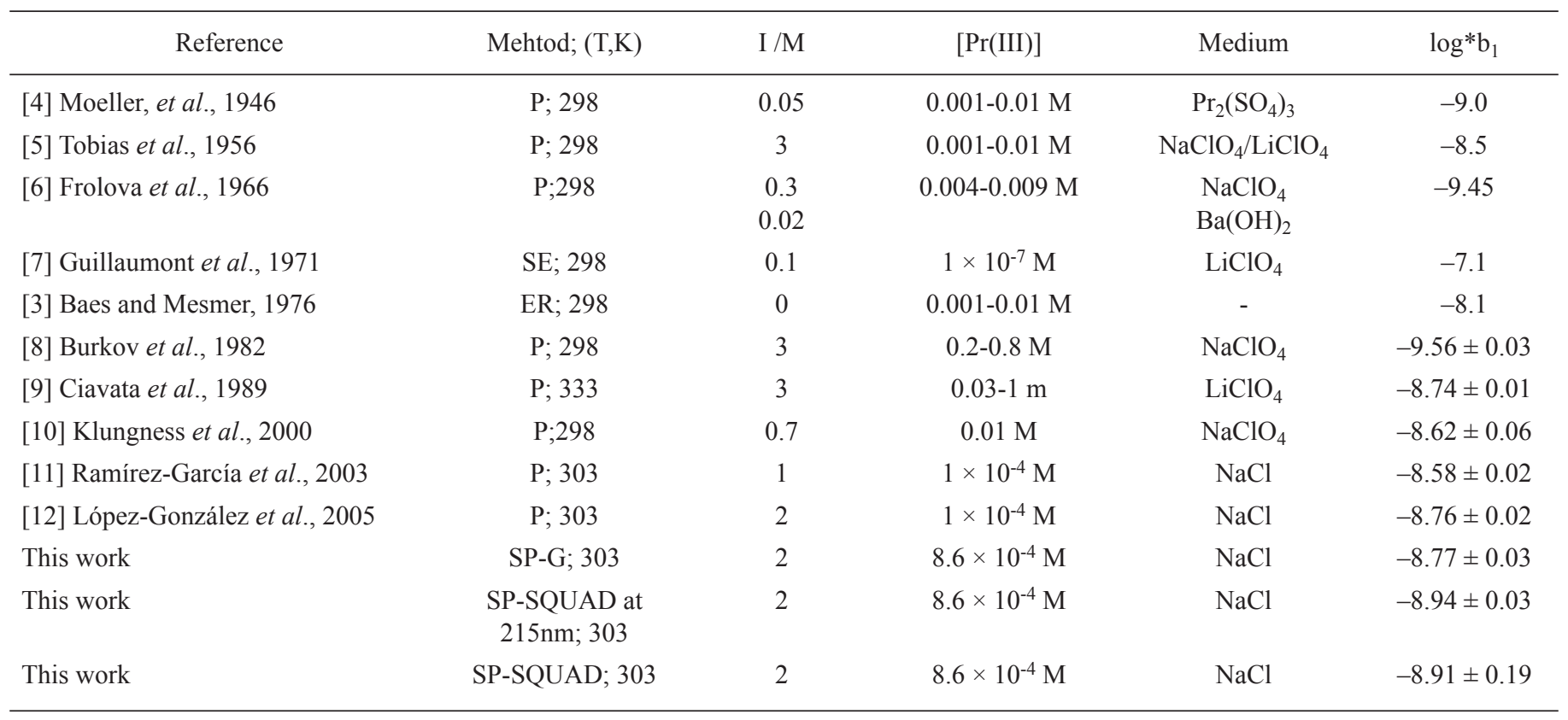

P: Potentiometric, ER: Empiric Relationship, SE: Solvent Extraction,

SP-G: Spectrophotometric Graphic Method, SP-SQUAD: Spectrophotometric processed by SQUAD. 


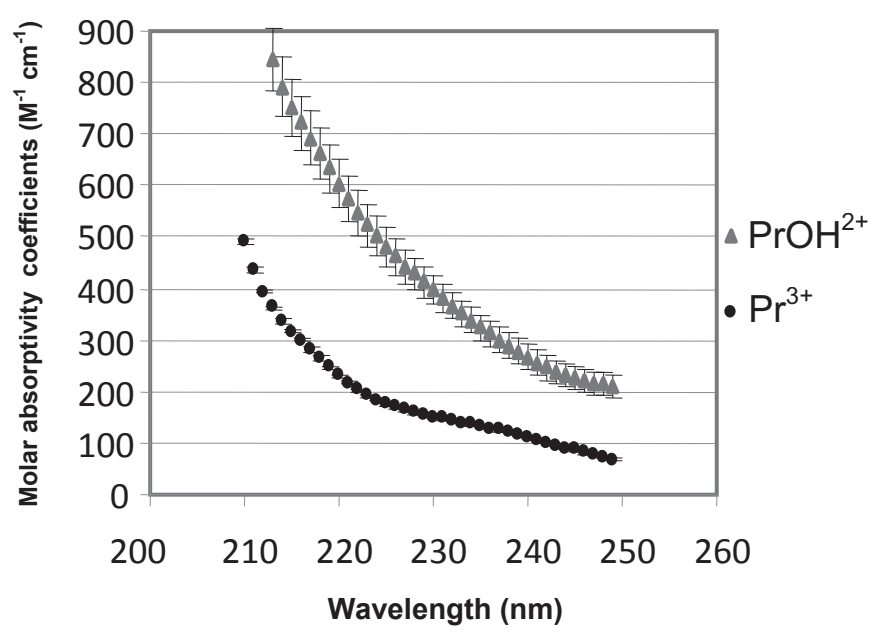

Fig. 4. Molar absorptivity coefficients as a function of wavelength, for $\operatorname{Pr}^{3+}$ and $\operatorname{Pr}(\mathrm{OH})^{2+}$ species determined with the program SQUAD.

\section{Conclusions}

The $\log * \beta_{1}$ value for the first hydrolysis of $\operatorname{Pr}($ III) has been determined spectrophotometrically at $303 \mathrm{~K}$ in $\mathrm{NaCl} 2 \mathrm{M}$, both graphically and with the aid of program SQUAD. Although the value obtained graphically is statistically equal to that reported previously by the potentiometric method [12], in the conditions of the present paper we have evidence that there are some points with presence of the solid phase corresponding to $\operatorname{Pr}(\mathrm{OH})_{3(\mathrm{~s})}$. The refined value obtained with SQUAD is statistically different by 0.17 units but it has been obtained in the absence of the solid. Then, it is necessary to obtain the first hydrolysis value with other methods, as suggested by IUPAC, in order to confirm the better estimator that could be recommended.

\section{Experimental}

\section{Instrumentation}

The reagents used were of analytical grade. To prepare the solutions and rinse the laboratory material, distilled water was used (1.3 Micromohs, obtained from a US BARNSTEAD equipment); particularly, just boiled for the sodium hydroxide solutions.

A Radiometer TIM900 Titrilab potentiometer was used, with a combined electrode for $\mathrm{pH}$ measurements, a $20 \mathrm{~mL}$ Radiometer ABU901 automatic burette with a minimum addition volume of $0.2 \%$ and a water bath temperature controller Cole Parmer Polystat, model 12105-30 with a precision of 0.1 $\mathrm{K}$ units. The potentiometer's uncertainty is of 0.001 in $\mathrm{pH}$. Before each of the experiments, the electrodes were calibrated with certified commercial solutions with $\mathrm{pH}$ of $4 \pm 0.01$ and 7 \pm 0.01 (Radiometer).
To carry out the spectrophometric titrations, a Perkin Elmer UV-Vis Lambda 10 spectrophometer was used with quartz cells of $1 \mathrm{~cm}$ optical path length.

\section{Preparation of $\mathrm{HCl}$ solutions}

For the preparation of the hydrochloric acid solutions, we started from $\mathrm{HCl} 1 \mathrm{M}$ (Merck, titrisol). Starting from this solution, all the others were prepared by dilution.

\section{Preparation of $\mathrm{NaOH}$ solutions}

To obtain the carbonate ion free $\mathrm{NaOH}$ solutions, the followed procedure was to prepare a $\mathrm{NaOH}$ solution at $50 \%$ weight/ volume. This solution was centrifuged to separate the aqueous phase from the precipitate (sodium carbonate, insoluble) $[19,25]$ and later, in a glove box with an atmosphere of $\mathrm{N}_{2}$ (Praxair, 99.99\%) at ambience temperature, an aliquot part of the supernatant liquid was taken (carbonate free aqueous solution) and it was diluted at 1 liter with distilled water, boiled and cold, in a volumetric flask. This caustic soda solution was titrated with potassium hydrogen phthalate (99.95\%, Aldrich) and the solutions needed for the experiments were prepared from it.

\section{Determination of the $\mathrm{pC}_{\mathrm{H}} / \mathrm{pH}$ relationship at $\mathrm{NaCl} 2 \mathrm{M}$}

The relation between the $\mathrm{pH}$ and the $\mathrm{pC}_{\mathrm{H}}\left(\mathrm{pC}_{\mathrm{H}}=-\log \left[\mathrm{H}^{+}\right]\right)$ was determined by the TIM900 potentiometer. For that, $10^{-1}$, $10^{-2}, 10^{-3} \mathrm{M} \mathrm{HCl}$ and same concentrations of $\mathrm{NaOH}$ solutions were prepared, in cold boiled water and all in the $2 \mathrm{M} \mathrm{NaCl}$ medium. The potentiometric measurements of these solutions are the ones considered as $\mathrm{pH}$ values. The alkaline solutions were prepared inside the glove box and were divided in aliquot parts, which were kept sealed until they were measured. During measurements a constant flux of nitrogen was applied over the solution. Each of these solutions was measured three times the same day they were prepared and the three days that followed. All measurements were made at $303 \mathrm{~K}$. The obtained data were averaged out and a graphic relating the hydrogen ion $\left(\mathrm{pC}_{\mathrm{H}}\right)$ concentration in both environments with the experimental $\mathrm{pH}$ was traced.

\section{Solutions of praseodymium}

The praseodymium stock solution was prepared starting from $\operatorname{Pr}_{6} \mathrm{O}_{11}(99.9 \%$, Aldrich Chemical). This compound is a mixture of $\operatorname{Pr}^{3+}$ and $\operatorname{Pr}^{4+}$ oxides and forms only $\operatorname{Pr}^{3+}$ in aqueous solutions [9]. The oxide was calcined according to recommendations in literature [26]. Once calcined and cold, a known quantity of $\operatorname{Pr}_{6} \mathrm{O}_{11}$ was weighed, this sample was dissolved in $15 \mathrm{~mL}$ of concentrated solution of $\mathrm{HCl}$ (36.5-38\%, Merck); this solution was evaporated almost to dryness, moved away from the heat in the last part and letting it evaporate by itself at room temperature, to obtain praseodymium chloride $\left(\mathrm{PrCl}_{3}\right)$. This procedure, from the addition of $15 \mathrm{~mL}$ of concentrated 
solution of $\mathrm{HCl}$, should be repeated by three times. Finally, the $\mathrm{PrCl}_{3}$ obtained was dissolved and diluted adequately with $1 \times$ $10^{-3} \mathrm{M} \mathrm{HCl}$ solution (initial $\mathrm{pH}=3$ ). The nominal concentration of the praseodymium (III) stock solution was $0.65 \mathrm{M}$.

When the stock praseodymium solution is prepared starting from its oxide, evaporation to dryness must be avoided, because then praseodymium hydroxide would form, which would stop subsequent evaporations from being carried out, since it's not water soluble.

The praseodymium in the standard solution was determined by titration $[27,28]$ with a 0.025 M EDTA solution (Baker) at $\mathrm{pH} 7.2$ adjusted with ammonia hydroxide solution. Three drops of pyridine and three drops of xylenol orange (Aldrich) were also added. The praseodymium concentration in the standard solution was $0.65 \mathrm{M}$. Starting from this solution, other solutions were made by dilution to obtain the calibration curves of praseodymium solutions by UV-Vis Spectrophotometry and for spectrophotometric titration.

\section{Calibration curves of praseodymium solutions by UV-Vis spectrophotometry}

To determine the absorption calibration curves, $10-\mathrm{cm}^{3}$ solutions of $0.0001,0.00065,0.0086,0.0013,0.0026,0.0065$, $0.026,0.065,0.125$ and $0.325 \mathrm{M}$, all at $\mathrm{pH} 3$ and with $2 \mathrm{M}$ $\mathrm{NaCl}$ were prepared using the $0.65 \mathrm{M}$ Pr standard solution. The absorbance vs. wavelength profiles of the resulting solutions were obtained in the range of 200-700 nm using a PerkinElmer UV/Vis Lambda 10 spectrophotometer .

The data treatment was processed with an Excel worksheet (Microsoft), to determine the relation absorbance in function to the wavelength.

\section{First hydrolysis constant determination of praseodymium (III)}

The photometric titrations were obtained by following a previously described methodology [22]. Briefly, a determined volume of the $0.65 \mathrm{M}$ Pr solution was transferred to a titration cell containing $20 \mathrm{~cm}^{3}$ of the $2 \mathrm{M} \mathrm{NaCl}$ solution (initial $\mathrm{pH}=3$ ). The transferred volume was enough to obtain a final $\mathrm{Pr}$ concentration of $10^{-3} \mathrm{M}$. The mixture was stirred for 7 minutes after which the solution's $\mathrm{pH}$ was recorded. Subsequently, an aliquot of $4 \mathrm{~cm}^{3}$ was taken from the reaction cell to determine the UV/Vis absorption, and the volume obtained was returned to the titration cell. After that, a known volume of the $5 \times 10^{-3} \mathrm{M} \mathrm{NaOH}$ in $2 \mathrm{M} \mathrm{NaCl}$ was added to the titration cell. After equilibration for 7 minutes, another aliquot was taken to determine the new $\mathrm{pH}$ and absorbance. The absorbance vs. wavelength profiles of the resulting solutions were obtained in the range of 200 to $700 \mathrm{~nm}$. The addition of the $\mathrm{NaOH}$ solution, $\mathrm{pH}$, and absorbance measurement was repeated until the $\mathrm{pH}$ was about 12. A nitrogen flux was maintained on the solution during the experiments. At least two experiments were performed under the same conditions to obtain reproducibility.
The $\mathrm{pH}$ measurements were carried out with a combined electrode (glass- $\mathrm{AgCl} / \mathrm{Ag}$ ), which has low interference coefficients for alkali ions. A pH-meter (Radiometer TIM900 Titrilab, France) together with an automatic burette (Radiometer ABU901, France), a double wall cell, and a constant-temperature circulator (Polyscience Circulator 12101-10, Perkin Elmer, Hayward, CA) with a precision of $0.001 \mathrm{pH}$ units were used. All the experiments were carried out at $303 \pm$ $0.1 \mathrm{~K}$ and a nitrogen flux was kept in the reaction cell to avoid the environmental $\mathrm{CO}_{2}$. The $\mathrm{pH}$ of the $\mathrm{NaCl}$ stock solutions was adjusted to 3 with $\mathrm{HCl}$ in order to prevent Pr hydrolysis before the experiments began. The experimental values of the $\mathrm{pH}$, absorbance, and volumes of $\mathrm{NaOH}$ added in each titration point were analyzed using the SQUAD [13] and graphic method [22]. The absorbance versus $\mathrm{pC}_{\mathrm{H}}$ data were plotted using the Excel program of MS Office $2000^{\circledR}$.

\section{Acknowledgements}

ARH want to acknowledge the support of CONACyT for a sabbatical leave in FESC-UNAM during 2009.

\section{References}

1. Lundquist, R. Acta Chem. Escand. 1982, A36, 741-750.

2. Moeller, T.; Martin, D. F.; Thompson, L. C.; Ferrus, R.; Feistel, R.; Randall, W. J. Chem. Rev. 1965, 65, 1-50.

3. Baes, Jr. Ch. F.; Mesmer, R.E. The Hydrolysis of Cations, Wiley, New York, 1976, 129-149.

4. Moeller, T.; Kremers, H. E. Chem. Rev. 1945, 37, 97-159.

5. Tobias, R.; Garret A. J. Am. Chem. Soc. 1956, 80, 3532-3537.

6. Frolova, U. K.; Kumok, V. N.; Serebrennikov, V. V. Izv. Bysshikh Uchebn. Zavedenii 1966, Khim. Teknol. 9, 176-179; CA: 65, 9816c.

7. Guillaumont, R.; Desiré, B.; Galin, M. Radiochem. Radioanal. Lett. 1971, 8, 189-198.

8. Burkov, K. A.; Bus'ko, E. A.; Pichugina, I. V. Russ. J. Inorg. Chem. 1982, 27, 362-364.

9. Ciavata, L., Porto, R., Vasca, E. Polyhedron 1989, 8, 983-989.

10. Klungness, G. D.; Byrne, R. H. Polyhedron 2000, 19, 99-107.

11. Ramírez-García, J. J.; Solache-Ríos, M.; Jiménez-Reyes, M.; Rojas-Hernández, A. J. Solution Chem. 2003, 33, 879-896.

12. López-González, H.; Jiménez-Reyes, M.; Solache-Ríos, M.; Ramírez-García, J. J.; Rojas-Hernández, A. J. Solution Chem. 2005, 34, 429- 443.

13. Leggett, D. J. Computational Methods for the Determination of Formation Constants, Plenum Press, New York, 1985, 159-220.

14. Canham, G. R. Descriptive Inorganic Chemistry, Addison Wesley, Longman, 1996, 465-475.

15. Vickery, R. C. Analytical Chemistry of the Rare Earths, Pergamon Press, New York, 1961, 81-94.

16. Treadwell, F. P. Analytical Chemistry, Vol. I, Qualitative Analysis, Wiley. Chapman and Hall, London, 1942, pp. 468-478.

17. Harris, E. W.; Kratochvil, B. An Introduction to Chemical Analysis, Saunders/CBS, Philadelphia, 1981, 370-423.

18. Burriel, F.; Lucena, F.; Arribas, S.; Hernández, J. Química Analítica Cualitativa, Ed. Paraninfo, México, 2002. Chapter 13.

19. Harris, D. C. Análisis Químico Cuantitativo, Reverté, México, 2001, 499-508. 
20. Rouessac, F.; Rouessac, A. Análisis Químico: Métodos y Técnicas Instrumentales Modernas, Mc Graw Hill, España, 2003, pp. 137167.

21. Tuck, D. G. Pure Appl. Chem. 1989, 61, 1161-1163.

22. Pinsuwan, S.; Álvarez-Núñez, F. A.; Tabibi, E.; Yalkowsky, S. H. J. Pharm. Sci. 1999, 88, 535-537.

23. Feldmann, I. Anal. Chem. 1956, 28, 1859-1866.

24. Miller, J. N.; Miller, J. C. Estadística y Quimiometría para Química Analítica, Pearson, Madrid, 2002, pp. 45-55, 263-265.
25. Ayres, G. H. Análisis Químico Cuantitativo, Harla, México, 1975, 333-336.

26. Sangina, Q. A. Rare Metals, Izdatel'stu Metallurgiya, Moskva, 1964, 192-194.

27. Fritz, J. S.; Oliver, R. T.; Pietrzik, D. J. Anal. Chem. 1958, 30, 1111-1114.

28. Charlot, G. Chimie Analytique Quantitative II, Sixième edition, Masson Et Cie, Paris, 1974, 538-539. 